\title{
Teaching: An Approach to the Rebirth of a New Career
}

\author{
Hernando Lintag Bernal Jr${ }^{1}$, Patrociño Canuto de Vera $\mathrm{II}^{2}$, Nieves Tagulao Salazar ${ }^{3}$ \\ ${ }^{1}$ General Education Department, Far Eastern University-NRMF, Quezon City, Philippines \\ ${ }^{2}$ Senior High School, Schools Division of Baguio City, Baguio City, Philippines \\ ${ }^{3}$ English Department, Division of City School, City of Pasig, Philippines
}

Email address:

bhambernal@gmail.com (H. L. B. Jr), patdevera@yahoo.com (P. C. de Vera II), peredes_1967@yahoo.com (N. T. Salazar)

\section{To cite this article:}

Hernando Lintag Bernal Jr, Patrociño Canuto de Vera II, Nieves Tagulao Salazar. Teaching: An Approach to the Rebirth of a New Career. Teacher Education and Curriculum Studies. Vol. 3, No. 2, 2018, pp. 14-19. doi: 10.11648/j.tecs.20180302.11

Received: September 25, 2018; Accepted: October 24, 2018; Published: November 19, 2018

\begin{abstract}
For the past decades, teaching as a second career was widely explored as a new career opportunity. This study aimed to examine the experiences of teachers who had a career shift from past careers to teaching in private and public schools and understand second career teachers who entered the teaching profession and how it is different from their previous career. The study made use of Phenomenological Study that explicates the meaning and lived experiences of second career teachers' continuance in their calling. The data was gathered from ten participants through a semi-structured interview. Transcription of interviews, as well as coding, sought to identify emergent themes and areas for further research. The study provided insight into the phenomenon of why people decided to shift careers to become teachers, as well as shed different points in their respective careers. Second career shifters may have many experiences previously, however, teaching to students regardless of bachelor course may be considered as a witness that getting into teaching the second time does not always mean the secondary. It was found out that career shifter teachers really like teaching and did not have any clamour in terms of doing the present job they have.
\end{abstract}

Keywords: Career Shifter, Second Career, Teaching Profession

\section{Introduction}

For the past decades, teaching as a second career was widely explored as a new career opportunity [1]. In fact, teaching career was one of the most captivating and stable professions that provides a high level of job security. In the past twelve years, there is a growing number of individuals who had left successful occupations unrelated to education to enter teacher preparation programs and become both private and public K-12 school teachers [2]. Despite the differences of their first career to teaching, the collective life wisdom of second-career teachers enables them to approach teaching with a multitude of responses to critical teaching situations.

[3] These teachers who had shifted careers could offer a wide variety of experiences compared to the teaching profession. Career shifter had a great deal in teaching profession that provides investigation which directly examines career change that causes potential life-changing event set into motion, including a desire for fulfillment and opportunities to serve the community.
The number of mature individuals entering teaching career as a second profession consistently increase for the past twenty years [4]. Usually, career change signifies one's place of employment and the length of time an individual spends in a different career. [5] A research had supported that the contemporary generation and beyond is more likely to change career for several times over the course of their working lives. This was due to the changes in the labor market condition. This could also be changes in the modern society in terms of technology, globalism, and economics [6]. This steady growth of career shifting coined the term "boundary less career" as indicator of the widespread change of job or profession during one's working lifetime [7].

These career changers are looking for work that may be more fulfilling and personally satisfying than their previous choice of profession. There could be varieties of factors to influence someone to change career. There are [8] factors such as stress and frustration in the previous career and feeling of isolation are commonly cited as motivations for someone to consider change of career into teaching. It could 
mean that those who are happy with their careers will not tend to shift into others even if it is of their interest. One of the reasons that there is a career shift is because of their personalities which may not fit into their previous career. This theory provides a possible explanation for those secondcareer teachers who have given up what are often wellpaying professions to seek a career more in line with their personality traits and value systems.

Researchers suggest that the reasons for choosing teaching as second career differs in terms of intrinsic and extrinsic factor. [5] There is the motivation of the career shifters was the intrinsic values.

A mature aged beginner teacher [9] study, put emphasis on altruistic elements that embedded a moral obligation to instil purpose for children, and help children to reach their potential. Enhancement of personal growth and looking for a challenge is another motivation of the new career teachers. For some instance career shifters has an inner desire to become a teacher for a long time but are waiting for the right moment to change career [3]. This could lead to a decision to fulfill the "realization of a long - held dreams" [10].

[11] A research had affirmed that teaching is more than helping a child master phonics or discovers meaning in lifeless history facts. It is more on ways to help each student to perceive learning as a means of attaining his goals rather than goals that are imposed on him by the school administrators. Humanistic Educator insists that teachers should be motivators rather than stressors of the student's drive to realize his own potentialities and to develop himself fully. Teachers are source of hope, model of discipline, help students learn to think for themselves, and changing the will not to yes, I can. Teachers are resource providers when it comes to giving ideas of instructional materials that will help the students to learn and to build leadership. But teaching knowledge and techniques are not enough. Teaching is more than a science or skill because it is in the bottom of the ability to fit in with the others' wavelength. Teaching profession is about constant love for students and giving them second chances to believe in them when no one else does. There is a research that [12] revealed that a person must obtain post-secondary education to have a decent work and must engaged in lifelong learning so that when it comes to teaching it will not be difficult to teach. Also, in becoming a teacher one must set rules to implement inside the class.

\subsection{Objectives}

Despite the increase of second career teachers, there are only few researches that study about their school experiences and their philosophical perspective. This study aimed to:

(1) Examine the experiences of teachers who had a career shift from past careers to teaching in private and public schools.

(2) Understand second career teachers who entered the teaching profession and how it is different from their previous career.

This study is for administrators, principals, teachers, students, and future researchers. Administrators for they are to realize the contribution of career shifters to the teaching industry; principals as they can help in evaluating the strengths and weaknesses of career shifters in the teaching instruction; teachers for they can be able to overcome barriers of the career shifters in entering the profession and avoiding diversifying teacher workforce; students for them to understand the perspectives of classroom teachers in providing rich insights into career change and philosophies after changing professions; and future researchers for future studies on better understanding of career shifter's philosophy, perspectives, and contributions in the teaching profession.

\subsection{Research Paradigm}

The present study aimed to determine the factors that affects the decision-making of some professionals from other field who transferred into teaching and the required experiences of the respondents from their past up to their present profession. The study began with an interview through unstructured questioning that was conducted to the respondents to know the reason of their career-shifting. Data gathered from the interview were transcribed. The outcomes of the interview were analyzed, evaluated and concluded. Ideas, perceptions and awareness of one's goal were presented based on the result of the study.

\begin{tabular}{|c|c|c|}
\hline $\begin{array}{l}\text { INPUT } \\
\text { Career shifter teachers } \\
\text { Teaching profession }\end{array}$ & $\begin{array}{l}\text { PROCESS } \\
\text { Interview } \\
\text { Transcription } \\
\text { Thematization }\end{array}$ & $\begin{array}{l}\text { OUTPUT } \\
\text { Seminars for career shifters to } \\
\text { teaching } \\
\text { Course programs for second } \\
\text { career shifters to teaching } \\
\text { Curriculum alignment of } \\
\text { previous career to teaching } \\
\text { career }\end{array}$ \\
\hline
\end{tabular}

Figure 1. Research paradigm on career shifter teachers.

\section{Methodology}

This part of the research presents the research design, procedure, and instrument used in the study.

\subsection{Research Design}

This study made use of Phenomenological Study that explicates the meaning and lived experiences of second 
career teachers' continuance in their calling. The data was gathered from ten participants through a semi-structured interview. Transcription of interviews, as well as coding, sought to identify emergent themes and areas for further research. The study provided insight into the phenomenon of why people decided to shift careers to become teachers, as well as shed different points in their respective careers.

\subsection{Procedure}

This study was conducted in the five (5) public schools and five (5) private schools in the Philippines. These places were selected to know the lived experiences of second career teachers.

The study made used of audio recorder with the approval of the respondents to transcript the verbatim of their lifeexperiences in teaching. The researchers keep the confidentiality of the respondents' personal information. The transcribe narratives were validated by the respondents right after it was rewritten. Any changes and verification upon evaluation of the participants were considered and corrected; with their approval, data gathered were included in the study completely as it were narrated.

Phenomenological Study was applied in the research. In the process, bracketing was applied to ensure that the acquired information was pure in form to gain all the usable information about the experiences, motivations, and reflections of second-career teachers. To ensure the depth and quality of the data gathered during the research process, the said method was used.

Ten (10) participants from diverse professions were chosen. They were interviewed as regard to their experiences as career shifters using a non-directed interview. All the participants met the qualifications of this research. Finally, the encountered challenges were noted by the researchers with the help of the recorded field notes, knowledge in the participants' narration, and converted the data into usable chunks of information.

Each interview was audio recorded and transcribed. The intention of the interviews was to reveal shared experiences that may be unique to the second-career teacher.

\subsection{Instruments}

This study collected data using a variety of instruments, including structured and follow-up interviews. All interviews were audio recorded and hand transcribed for accuracy. Digital recording devices were used to ensure that all data were properly collected, the second recorder served as a failsafe to the first. All collected data were then encoded to gain additional insight and to allow themes to emerge. Follow-up sessions were based upon issues and questions raised during the initial interviews and observations as identified in the coding process. Also, books, thesis, researches and other reliable resources were used to validate and add integrity to this study.

\section{Result and Discussion}

There were different themes that came up from the interviews done with the ten teachers coming from different schools. These themes were divided according to the research questions of this study. The first question was on the experiences before the teachers had their teaching career shift. The second question was on the differences of the teaching career from their previous careers.

Experiences before the career shift

The time that these teachers first had their career shift was when they were taking their bachelor courses. Their first courses were Business, Communication, Computer, Medical, and other undefined programs as they were not mentioned during the interview. In one of the conversations it was stated, 'Before I became a teacher, I graduated from a different program'. As these were their previous courses, upon graduation, they were also employed in different companies and had clerical works, teaching related but in another form as in online teaching which was shown in the following lines: 'I was a former Korean English teacher'. Likewise, in the medical field as in 'I graduated as a nurse and worked at St. Luke's'. After few years of experiences, these teachers were able to realize that they are into teaching. Thus, these teachers took education units and had passed the board exam for teachers which was given by the Philippine government. In so doing, they were able to teach in private schools before teaching in the government schools as shown in the dialogue: 'I did not enjoy what I was doing so right then, I decided to start taking CTP for Education'. One of the teachers really wanted to pursue education as he thinks that teaching is really a dream and a passion as in 'I really wanted to pursue the teaching profession thus, I decided to continue the education I left when I was taking up education units before while I was a student of HRM.' In some cases, while teaching in the private school and while enjoying her first work, she still realized that teaching is more fulfilling and more engaging. The respondent stated, 'I may have enjoyed my first work, but it makes me more fulfilled after I engaged myself into teaching. Money was never important in the teaching field rather the lessons you can learn from the students', which means that her students may have an impact to her and vice versa.

\section{Differences of teaching to previous careers}

Teaching is a different type of career. It was proven by a lot of individuals who experienced it and had been experiencing it. There were many challenges in the work place, in the classroom, and in the management of time. There were also challenges in the employment sector, with the educational system, and in the financial and spiritual life struggles of those who are in the teaching field. These teachers were not exempted from these challenges.

Being in the workplace is getting along with others not only to the students but to teachers and principals, as well. One teacher stated,

'Sobrang maninibago ka sa pagtuturo kase SA OFFICE NAKA UPO KA LANG, pagdating mo sa pagtuturo madami 
kang pakikisamahan, hindi lang mga bata, pati mga teachers at principal. Lagi e checheck yung lesson plan so dapat lagi kang may gawa. Tapos syempre dapat lagi kang di malelate. Ang kaibahan kase sa pagtuturo pag minsan dadalhin mo pa lahat ng test paper mo since sa school ka magsusulat or gagawa ng lesson plan sa office kase wala kang dadalhin kase papasok ka at uuwi ka ng walang dalang gamit.'

Being in the workplace such as school means getting late and doing things as the school requires. Classroom challenges are more meaningful as every day is a new day to teacher and that there was never a time that teaching became boring. From the interview, one of the teachers stated,

'As a teacher, every day is a new day, you never get bored. When you enter the classroom, you have no idea what is going to happen. One minute you can have a parent

yelling at you, and the next you can find out that the whole class passed their exam with flying colors.'

There is a possibility that these teachers were really amazed as to how a lot of things were going on. There were projects and activities that need to be done and the learners are really giving out their best although many of them were not blessed materially. A teacher had really witnessed,

'I can see children when having quiz, they are borrowing pens with each other. Then you are going to have a project or a simple activity then they do not have any material. You will realize that it is difficult, you should not be a teacher if you do not know how to show love. There's a lot of students that do not have enough money or allowance. This is where you will learn how to give".

Some teachers had a change of heart upon witnessing such things. Others had given a lot of life learnings in terms of doing things. The teacher had learned valuable lessons on giving which may not mattered in his previous experiences when he was not a teacher. In the same manner, a second career teacher had thought of teaching as a rewarding profession. He emphasized that,

'If you want to give out what you have, give it on your last moment where your strength is so when you grow old you'll go back to your strength. And I find it in teaching.

That is why I leave the publication where I am working -and if you ask me to leave this profession, you can never ask me to do it.

Truly, being in the teaching profession has its rewards. Strengths of teachers could be given in different forms as well. That it could lead to self-reflection. A teacher had stated it in this way:

'Sa teaching naman sinasabi ko na hindi mo panghihinayang. Darating rin yung time na mawawalan $k a$ ng gana, pero marerevive mo ulit yung energy mo, yungenthusiasm mo, Yung kagustuhan mo magturo kase napaka rewarding naman. Minsan hindi mo nakilala yung bata pero kilala ka pa, pupunta sayo, dadalhan ka ng saging para magpasalamat at aalalahanin ka at mag-hi sa iyo.'

Yes, teaching really has its rewards and its benefits which would lead up to a lifetime's memories. In another reflection of a teacher, he was amazed that the students he was handling really takes time to talk to him even outside the classroom as in,

'When I was teaching in lower section, after the class hour or outside the school or classroom my students will come to me to ask questions and I will teach them. Even in a basketball court when they see me they will ask me "sir, how did this solution happen?'

The teacher may not have this type of experience previously. It is possible that in his previous works, he just finishes his work then goes home without encountering any other circumstances beyond what transcribed during the day's work. The teacher might have then caught up with the student's interest in his subject that he has decided how teaching is really rewarding and challenging every day.

Looking at how the research was written, it could be observed that most of the insights were all in the positive difficulties of teaching. However, as much as it cannot be stated, there are still negative difficulties encountered by the second career shifter teachers. These include the educational system of the Philippines and the financial and spiritual struggles that they are facing. Majority of the teachers that were interviewed had stated that it was the number of students and the workload given by the school they were assigned to that had them shocked in the first place. They were surprised that the transition from private to public schools was different in terms of their lives and their attitudes and behaviors.

'Unang una dyan yung sa dami ng mga bata sa public ha. Sobrang daming mga bata. Tapos iba iba yung gusto nila sa buhay, iba-iba rin ang mga ugali. Tapos dun na pumapasok yung sa maisabuhay mo yung mga sinasabi ng propesor mo noon na "understanding", yung sa learners. Mahalaga na maisabuhay mo yun."

It is very important for teachers to be understanding with their learners. If in school the teachers found it difficult to understand the word 'understand' as overemphasized by their professors, probably this time that they were in the government schools and they call it as the 'educational system', these second career shifter learners are really finding it easy to understand the word 'understand'. From these struggles of teachers, it resulted to financial and spiritual struggles. Really, these teachers call their financial struggles as being in 'LONDON, Yung loan dito- loan doon'. That is, the teachers are into loaning or borrowing money from different agencies such as Government Security Insurance System (GSIS), banks, or in some cases, personal lending from their friends or their relatives. These happen usually if the teachers do not know how to budget their salaries. Likewise, in terms of spiritual struggles, these happens when the teacher is having a conflict with his coteachers. That from it, one of the teachers quoted Joharis Window, a sociologist,

'na hindi lahat ng tao ay kilala mo. At the same time hindi rin nila alam ang tunay mong ugali o may ugali ka rin na hindi nila alam.'

Some of the teachers are into an adjustment with people who do not have the same attitude and behavior as the others, as well as who do not have the same previous experiences as 
them. Some teachers were culturally shocked as they did not expect the way people deal with them and vice versa. A second reason for a spiritual struggle happens when these teachers are having seminars on the days that they are supposed to be going to church. A certain teacher stated that,

"May pagkakataon kase na gusto mo sanang magsimba kaso hindi mo na magawang magsimba dahil may seminar ka o may kailangan kang gawin."

Based from the above statement, some teachers really put God as first in their teaching lives. If not first, then, they give importance to a Divine Being to be part of their classroom lives and work challenge lives, however, resulting to a spiritual struggle.

\section{Summary of Findings}

It was found out in this research that career shifter teachers really like teaching and did not have any clamour in terms of doing the present job they have. These teachers have different bachelor courses prior to the real 'classroom' teaching which includes Business, Communication, Computer, Medical, and others. After graduation, their work experiences vary largely too, one would question how teaching was related to it. However, still they found the path to their passion, their love, and their dreams. Some teachers have done clerical, online, and medical works. When they saw opportunities in the teaching field, these teachers took education units, eventually leading to taking up the Licensure Examination Board for Teacher (LET Exam).

The employment of these teachers did not hinder them to continue to become catalyzers of change to their students. They were faced with challenges as in their workplace environment and time management install them to be who they are not. This involves challenges in the employability, encounters with students as well as with teachers, and with the struggle on the educational system, and lastly, with the financial and spiritual aspects.

\section{Conclusions}

Second career shifters may have many experiences previously, however, teaching to students regardless of bachelor course may be considered as a witness that getting into teaching the second time does not always mean the secondary. However, it only means getting it the 'second time around' while waiting for opportunities to strike. Therefore, teachers of the second careers maybe considered wellrounded in other forms.

\section{Recommendations}

This study would like to recommend three things. First is for the second career shifters. That is, it would have been better if the second career teachers had researched previously what they would be encountering once they are in the field of teaching. If in a private school, what was the school's history with teachers and students, will it lead to a good future or not and other else that leads for the betterment of the person as well? Likewise, if in a government school, what was the government's previous dealings with teachers in terms of salaries, laws, and rights, and what could be the newest developments that the government has mandated with teachers of second careers, if there are any?

The second recommendation is for the administrators. That is, it would have been better if the administrators make necessary seminars for the orientation of these second career teachers, exclusively for them. These second career teachers are really adjusting to teaching life as they may not be so used to it considering their previous careers. This might mean seminars in three aspects of life: mental, moral, and most especially emotional. The other aspects may not be included - physical and spiritual - as they might have different ways in carrying themselves considering their physique and their beliefs.

Third recommendation is for the non-shifter teachers as they had teaching as their first career and had understood better the teaching field. It is better if they are the ones to guide these second career teachers in terms of emotional and social understanding of the workplace and in dealing with people - the school administrators, parents, students, and other stakeholders.

\section{References}

[1] Novak, D. \& Knowles, J. (1992) Life Histories and Transition to Teaching as a Second Career. Report No. SPO34016. ERIC Document Reproduction Service No. ED 349285. Washington, DC: Office of Education, Bureau of Research.

[2] Chope, R. (2005) Qualitatively Assessing Family Influence in Career Decision Making: Journal of Career Assessment Retrieved from https://doi.org/10.1177/1069072705277913.

[3] Crow, G. \& Levine, L. (1990) No More Business as Usual: Career Changers Who Become Teachers: American Journal of Education Retrieved from

https://www.journals.uchicago.edu/doi/abs/10.1086/443956.

[4] Manuel, J. \& Hughes, J. 2006. It has always been my dream: exploring pre-service for choosing to teach. Teacher Development. 10(1): 524.

[5] Watt, H. \& Richardson, P. (2008). Motivations, perceptions, and aspirations concerning teaching as a career for different types of beginning teachers. Learning and Instruction, 18, 408-428.

[6] Powers, F. (2002) Second-career teachers: Perceptions and mission in their new careers, International Studies in Sociology of Education, 12:3, 303-318, DOI: 10.1080/09620210200200095.

[7] Lee, D. (2011) Changing Course: Reflection of Second-Career Teachers, Current Issues in Education Retrieved from file://Users/BB/Downloads/683-Article\%20Text-2814-2-1020110527.pdf.

[8] Serow, R. \& Forrest, K. (1994). Motives and circumstances: Occupational-change experiences of prospective late-entry teachers. Teaching \& Teacher Education, 10(5), 555-563. 
[9] Evans P. (2011) The changing pictures of the relationship between career and family: Retrieved from https://onlinelibrary.wiley.com/doi/abs/10.1002/job.40300501 03 .

[10] Williams, J. (2008). The motivations of career change students in teacher education: Asia-Pacific Journal of Teachers Education Retrieved from https://www.tandfonline.com/doi/abs/10.1080/1359866080260 7673.
[11] Miller, J. (1992). National career development guidelines. (ERIC Document Reproduction No. ED 347 493). Retrieved June 18, 2002, from http://www.ed.gov/databases/ERIC_Digests/ed347493.html.

[12] Miyake, A., \& Friedman, N. P. (2012). The Nature and Organization of Individual Differences in Executive Functions: Four General Conclusions. Current Directions in Psychological Science, 21, 8-14. 